Revista Mídia e Cotidiano

ISSN: 2178-602X

Artigo Seção Temática

Volume 15, Número 2, maio/ago. de 2021

Submetido em: 22/02/2021

Aprovado em: 28/04/2021

\title{
Quando tudo se inflama: levantes, violência, imagem ${ }^{1 ; 2}$
}

When everything burns: uprisings, violence, image

\author{
Cuando todo arde: levantamientos, violencia, imagen
}

\author{
Leandro Rodrigues $\mathrm{LAGE}^{3}$
}

\section{Resumo}

Este trabalho tem por objetivo analisar e discutir dimensões estéticas e políticas de imagens fotográficas alusivas aos atos e protestos antirracistas ocorridos em 2020. O objetivo é tensionar as diferentes figurações da violência nas imagens de manifestações do movimento \#vidasnegrasimportam e das mobilizações pelo Dia da Consciência Negra no Brasil, buscando discutir: a experiência da violência como motivação das insurgências, a violência subjacente aos gestos de sublevação, a violência empreendida para controlar os levantes e, por fim, a força percussiva das próprias imagens. Colocar essas imagens sob escrutínio significa, de um ponto de vista metodológico, fazer não apenas uma crítica dos levantes, mas propor também uma crítica da violência e do modo como as imagens operam diante das potências e formas de poder que atravessam essas manifestações em diferentes direções. Às imagens em análise, selecionadas com base, principalmente, em sua ampla circulação, coube fazer uma síntese das emoções da revolta e testemunhar, a partir do olho da história, os momentos em que o monopólio da violência é exercido e também posto à prova, em que a violência se opõe à própria violência, em que tudo se inflama e o páthos da indignação é não somente representado, mas também visualmente expresso.

Palavras-chave: Levantes. Violência. Imagem. Racismo. Fotografia.

\section{Abstract}

This article aims to analyze the aesthetic and political dimensions of photographic images of the anti-racist acts and protests that took place in 2020. The objective is to discuss the

\footnotetext{
${ }^{1}$ Este trabalho foi desenvolvido a partir do projeto de pesquisa "Levantes amazônicos: dimensões estéticas e políticas das imagens da resistência”, financiado pelo Conselho Nacional de Desenvolvimento Científico e Tecnológico (CNPq), com bolsas de iniciação científica vinculadas à Fundação Amazônia de Amparo a Estudos e Pesquisas (FAPESPA) e à Universidade Federal do Pará (UFPA).

${ }^{2}$ Agradeço às discentes Julia França e Heloiá Carneiro, vinculadas ao curso de Jornalismo da Faculdade de Comunicação da UFPA e bolsistas de Iniciação Científica do projeto "Levantes amazônicos", pelo auxílio na seleção de imagens e revisão deste trabalho.

${ }^{3}$ Docente da Faculdade de Comunicação e pesquisador do Programa de Pós-Graduação em Comunicação, Cultura e Amazônia, UFPA, Brasil. E-mail: leandrolage@ufpa.br. ORCID: 0000-0002-6814-9640.
} 
different figures of violence in the images of protests of the movement \#blacklivesmatter and the mobilizations for Black Awareness Day in Brazil, seeking to observe: the experience of violence as motivation of the insurgencies, the violence underlying the gestures of upheaval, the violence undertaken to suppress the uprisings and, finally, the percussive force of the images. Taking these images into account means, from a methodological point of view, not only to criticize the uprisings, but also to propose a criticism of the violence and the way the images operate in the face of the powers and forms of power that cross these manifestations in different directions. The images under analysis, chosen based on their wide circulation, were responsible for synthesizing the emotions of the revolt and witnessing, from the eye of history, the moments when the monopoly of violence is exercised and also put to the test, in which the violence is opposed to violence itself, in which everything burns and the pathos of indignation is not only represented, but also visually expressed.

Keywords: Uprisings. Violence. Image. Racism. Photography.

\section{Resumen}

Este artículo busca analizar las dimensiones estéticas y políticas de las imágenes fotográficas de los actos y protestas antirracistas ocurridas en 2020. El objetivo es discutir las diferentes figuras de la violencia en las imágenes de protestas del movimiento \#blacklivesmatter y las movilizaciones para el Día de la Conciencia Negra en Brasil, buscando observar: la experiencia de la violencia como motivación de las insurgencias, la violencia subyacente a los gestos de agitación, la violencia emprendida para reprimir los levantamientos y, finalmente, la fuerza percusiva de las imágenes. Tener en cuenta estas imágenes significa, desde un punto de vista metodológico, no solo criticar los levantamientos, sino también proponer una crítica a la violencia y la forma en que operan las imágenes frente a los poderes y formas de poder que atraviesan estas manifestaciones en diferentes direcciones. Las imágenes analizadas, elegidas en función de su amplia circulación, fueron las encargadas de sintetizar las emociones de la revuelta y de presenciar, desde el ojo de la historia, los momentos en los que se ejerce y también se pone a prueba el monopolio de la violencia, en los que la violencia se opone a la violencia misma, en la que todo arde y el pathos de la indignación no solo se representa, sino que también se expresa visualmente.

Palabras clave: Levantamientos. Violencia. Imagen. Racismo. Fotografía.

\section{Introdução}

Em 2020, diversos países do Ocidente - entre eles o Brasil, mas, em especial, os Estados Unidos da América - experimentaram ondas de protestos e manifestações contra atos, discursos, políticas e crimes com motivações racistas. O estopim para esses acontecimentos ocorreu em 25 de maio, na cidade de Minneapolis, no estado norteamericano de Minnesota. George Perry Floyd Jr., um homem negro de 46 anos, foi 


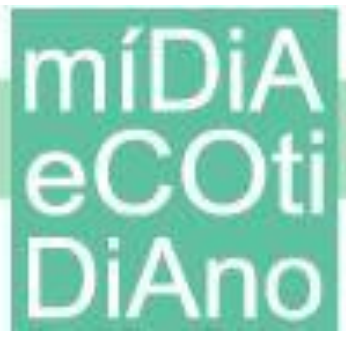

acusado de tentar usar notas falsas para comprar cigarros e, em seguida, detido por policiais, que o derrubaram e mantiveram-no sob domínio, com o joelho em seu pescoço, o que resultou na morte de Floyd por parada cardíaca causada pela asfixia mecânica. A violenta e desastrosa abordagem policial foi filmada por testemunhas e as imagens daquele crime circularam massivamente pela internet minutos depois do ocorrido.

O registro, a ampla circulação daquelas imagens e a reação imediata, indignada, crescente e violenta ao episódio, em diferentes países, são dignos não apenas do registro histórico, mas de discussões sobre o lugar de protagonismo das imagens quando, como diria G. Didi-Huberman, "tudo se inflama" (2017a). As imagens inscrevem-se no núcleo dos levantes, representando-os e, também, sintetizando emoções da revolta. Imagens como as do caso de George Floyd, assim como de outros episódios e da própria experiência histórica de violência racista, testemunham, a partir do olho da história, os momentos em que o monopólio da violência é exercido e posto à prova, em que a violência se opõe à própria violência, em que o páthos da indignação é registrado, expresso, reverberado.

Este trabalho tem por objetivo analisar e discutir dimensões estéticas e políticas de imagens fotográficas relacionadas a atos e protestos contra o racismo ocorridos no ano de 2020. O objetivo é tensionar as diferentes figurações da violência nas imagens de manifestações do movimento \#vidasnegrasimportam e das mobilizações pelo Dia da Consciência Negra no Brasil, buscando discutir: a experiência da violência como motivação das insurgências, a violência subjacente aos gestos de sublevação, a violência empreendida para controlar os levantes e, por fim, a força percussiva das próprias imagens. O texto é vinculado ao projeto de pesquisa "Levantes amazônicos: dimensões estéticas e políticas das imagens da resistência", voltado às imagens de levantes em seu trabalho de dar forma visível aos afetos da indignação, da convicção, do desejo e das demais emoções e sentimentos que animam essas insurreições.

\section{Em torno da violência dos levantes: premissas}

Um levante caracteriza-se como ação política empreendida por indivíduos ou grupos de pessoas subjugados a um regime ou forma específica de poder, na qual resolvem assumir os riscos de contestá-lo de forma explícita, com frequência no espaço 


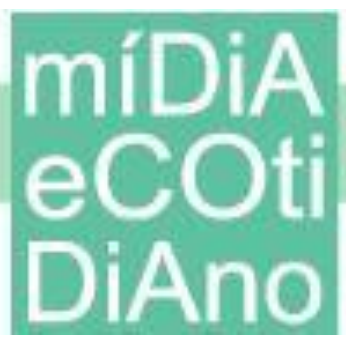

público, pondo em prática e tornando visíveis gestos de resistência catalisados pela indignação, pela convicção, pelo sentimento de injustiça e pelo desejo de emancipação. Essa definição, um tanto generalista, depreende-se principalmente dos trabalhos mais recentes do filósofo e historiador das imagens francês Georges Didi-Huberman (2017a, 2017b, 2019) e também de outros autores contemporâneos, tais como Judith Butler (2017, 2018), Jacques Rancière (2017, 2012), Alain Badiou (2012), Étienne Balibar (2015). A riqueza conceitual desse termo não reside apenas na literalidade pragmática do levante como revolta que se concretiza no espaço público, mas também naquilo que o termo oferece como metáfora da potência dos corpos e da resistência dos desejos. Sobretudo o desejo de escapar das condições de opressão e de sujeição. Assim, em oposição à submissão, "o desejo contrário - a sobrevivência do desejo nesse espaço concebido para neutralizá-lo - ganha todo sentido a partir da palavra levante e do gesto que ela pressupõe" (DIDI-HUBERMAN, 2017a, p. 16, grifo do autor).

Um dos aspectos mais centrais do debate em torno dos levantes e de suas manifestações nos mais diversos regimes de visibilidade, do fotojornalismo ao campo das artes, é sua estreita vinculação com a violência. Não se quer, com essa associação, reforçar o conhecido enquadramento criminalizante das manifestações no espaço público, tampouco fazer das dimensões agonísticas do levante o cerne dessas ações, negligenciando todo seu potencial transformador da realidade, mobilizador de formas de solidariedade e questionador de estruturas rígidas de opressão. Buscamos pôr em perspectiva a relação ambígua e multilateral entre levante e violência, assumindo como premissa que insurgir-se pressupõe uma dynamis, uma energia transgressora, desobediente, movente, deslocadora de pessoas, objetos, espaços, valores, ideias. "Não se recusa, não se desobedece, não se revolta, não se levanta sem violência, não importa em que grau", reconhece Didi-Huberman (2017b, p. 367). Mesmo ressaltando os riscos de que a violência "perverta", por assim dizer, o levante de suas motivações legítimas, o filósofo leva a sério as lições deixadas por Walter Benjamin (1986) sobre a necessidade de se fazer uma crítica permanente da violência e de sua historicidade, sem opô-la, $a$ priori, ao direito de se sublevar.

O segundo aspecto remete à própria (multi)dimensão ética da violência das sublevações. Ao assumirmos a violência como fenômeno subjacente aos levantes, é 


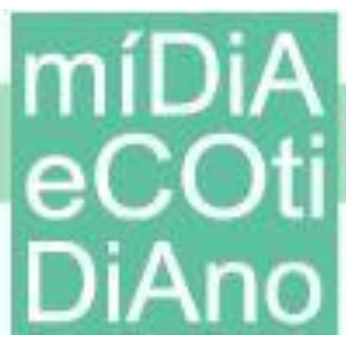

preciso suspender temporariamente a condenação ética, encarando a seriedade da questão segundo a qual a violência pode surgir como um meio para fins justos ou injustos. Em Crítica da violência, W. Benjamin (1986) nos lembra que a distinção da violência para fins justos ou injustos é historicamente sancionada pelo poder jurídico, que define os momentos, os atores e os fins para os quais o uso da violência é autorizado. "Através de que função a violência parece, com toda a razão, tão ameaçadora para o direito, tão temida por ele? Isso se mostra justamente nos casos em que, mesmo segundo a ordem judiciária atual, o emprego da violência ainda é admitido" (BENJAMIN, 1986, p. 163). Os exemplos são variados e, infelizmente, contemporâneos: as guerras, a ação policial, a defesa internacional... Para Benjamin, a questão de fundo é, justamente, a da violência como possibilidade muitas vezes única de questionamento da ordem e das instituições que distribuem a sanção e a legitimidade das violências - por corolário, seu acobertamento, sua cumplicidade. Ao fim e ao cabo, o que parece importar para o filósofo não é tomar partido na querela ética da violência, mas acenar para o fato de que "a crítica da violência, ou seja, a crítica do poder, é a filosofia de sua história" (BENJAMIN, 1986, p. 174). Nesse sentido, qualquer que seja a aparição da violência, seja como instrumento repressivo, seja como recurso contra violências estruturais, carece de uma crítica de fundo histórico, uma espécie de arqueologia que investigue suas raízes muitas vezes subterrâneas no solo do tempo.

A terceira e última premissa relacionada à violência diz respeito a uma relação tripla, explorada por Jean-Luc Nancy (2000): primeiro, a violência deve ser tomada, em seu sentido elementar, como uma força que se impõe, isto é, realiza-se de modo impositivo; segundo, a violência não está a serviço de uma verdade, pois ela própria reivindica sua verdade pela força; terceiro, a violência e a manifestação da violência são indissociáveis: "onde a força é simplesmente executiva, onde a autoridade é simplesmente imperativa, onde a lei é (em princípio) simplesmente coercitiva, a violência acrescenta outra coisa: ela se quer demonstrativa e monstruosa. Ela mostra-se a si e seu próprio efeito" (NANCY, 2000, p. 5, tradução nossa). Essas relações levam à síntese dessa premissa fundamental, que se refere à dimensão imagética da violência. "O violador quer ver sua marca sobre aquele que foi violado, e a violência consiste precisamente em imprimir essa marca" (NANCY, 2000, p. 5, tradução nossa). Se, inversamente, também 


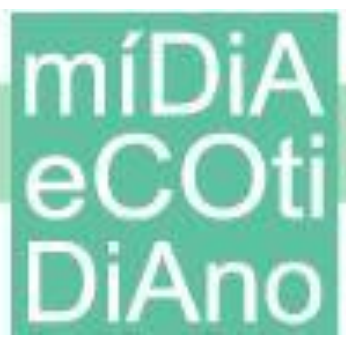

podemos dizer que a própria imagem consiste num golpe no tempo e na experiência evanescente das coisas e das pessoas, é de difícil refutação a ideia de que subjaz à violência sua re-produção em imagem, sua figuração, ainda que como marca escondida nos recantos mais borrados do inconsciente.

Uma vez explorados esses pressupostos, passemos a um exercício de crítica da violência enquanto trabalho da imagem, pensando suas dimensões figurativa, expressiva, a propósito de imagens alusivas aos levantes antirracistas.

\section{A imagem e a crítica histórica da violência}

As manifestações iniciadas em maio, após o assassinato de George Floyd nos EUA, estenderam-se pelas semanas e até pelos meses seguintes, também em outros países, tais como Espanha, Itália, Reino Unido, Brasil... Lideranças políticas internacionais e importantes instituições, como a Organização das Nações Unidas e a própria Igreja Católica, representada pelo Papa Francisco, condenaram a violência racista e criticaram o posicionamento do governo de Donald Trump. Os protestos foram às ruas mesmo em meio a um quadro mundial de agravamento da pandemia do Novo Coronavírus (SARS-CoV-2). Em diversos estados dos EUA, os protestos culminaram em confrontos entre a polícia e os manifestantes, além de saques, bloqueios e quebra-quebras. A indignação com o caso George Floyd ecoou internacionalmente e passou a ser referenciada, tanto nos cartazes de rua quanto na internet, pela expressão "black lives matter" (do inglês, vidas negras importam). Esse grito de guerra antirracista não é exatamente recente. O movimento Black Lives Matter foi criado em 2013, a partir de um texto publicado pela ativista Alicia Garza em sua rede social, em que repudiava a absolvição do homem responsável pela morte do adolescente negro Trayvon Martin, em 2012, no estado da Flórida (EUA). As ativistas Patrisse Cullors e Opal Tometi juntaramse a Alicia Garza para criar a organização, transformada em uma rede global (https://blacklivesmatter.com/), que se identifica como “[...] intervenção ideológica e política em um mundo onde as vidas dos negros são sistematicamente e intencionalmente alvos de morte. É uma afirmação da humanidade do povo negro, nossas contribuições para esta sociedade e nossa resiliência diante da opressão mortal". 
No Brasil, um país também marcado pelo racismo estrutural, entranhado em nossa história cultural, e pelos crimes com motivação racista, a expressão "vidas negras importam" - transformada em hashtag - foi amplamente utilizada na internet e em manifestações nas ruas, em diversas capitais. Em alguns casos, os manifestantes fizeram alusão a outros assassinatos de grande comoção, como o de João Pedro, adolescente de 14 anos baleado dentro de casa por um policial durante uma operação na cidade do Rio de Janeiro, em março de 2020. Meses após o período de intensa mobilização, a discussão e os protestos contra o racismo voltaram à tona em novembro, com a divulgação de um vídeo em que João Alberto Silveira Freitas, um homem negro de 40 anos, foi espancado e asfixiado até a morte pelos seguranças no estacionamento de um supermercado em Porto Alegre (RS). O crime ocorreu em 19 de novembro de 2020, um dia antes da data em que é celebrado no Brasil o Dia da Consciência Negra, efeméride criada em homenagem a Zumbi dos Palmares, líder quilombola que lutou contra o sistema escravista no Brasil. A morte de Beto, como era chamado, recebeu intensa cobertura midiática e gerou forte comoção pública, provocando inúmeros protestos em diversas cidades do país.

Para falarmos das relações entre violência, levantes e imagens, é preciso, em primeiro lugar, perguntarmo-nos sobre a experiência da violência como motivação, isto é, como catalisadora das insurgências. Assumimos, de saída, o pressuposto benjaminiano de que realizar uma crítica da violência demanda sua historicização, isto é, o reconhecimento de que a violência não está suspensa no tempo, mas inscreve-se numa cadeia de eventos nem sempre interligados de modo explícito. É nessa direção que segue a argumentação de Frantz Fanon sobre a violência como mediação fundamental da relação entre colonizados e colonizadores. Em seu clássico Os condenados da terra (1968), o autor caribenho analisa o processo de independência da Argélia e ressalta pelo menos duas premissas fundamentais para uma crítica da violência, a propósito das revoltas e (contra)ataques do povo argelino ante o domínio colonial francês: em primeiro lugar, a violência não teve início pelos colonizados, mas pelos colonizadores; em segundo lugar, para os "filhos da violência", que dela extraem sua humanidade, ela é a única forma conhecida de reapropriação, pelo homem, de seu destino. 
A violência que presidiu ao arranjo do mundo colonial, que ritmou incansavelmente a destruição das formas sociais indígenas, que arrasou completamente os sistemas de referências da economia, os modos da aparência e do vestuário, será reivindicada e assumida pelo colonizado no momento em que, decidindo ser a história em atos, a massa colonizada se engolfar nas cidades interditas. Fazer explodir o mundo colonial é doravante uma imagem de ação muito clara, muito compreensível e que pode ser retomada por cada um dos indivíduos que constituem o povo colonizado. Desmanchar o mundo colonial não significa que depois da abolição das fronteiras se vão abrir vias de passagem entre as duas zonas. Destruir o mundo colonial é, nem mais nem menos, abolir uma zona, enterrá-la profundamente no solo ou expulsá-la do território (FANON, 1968, p. 30).

Engana-se quem enxerga na crítica de Fanon apenas uma apologia radical à violência. Como o diz Sartre, no prefácio ao livro, essa "violência irreprimível [...] não é uma tempestade absurda nem a ressurreição de instintos selvagens e nem mesmo um efeito do ressentimento; é o próprio homem que se recompõe" (SARTRE, 1968, p. 14). Depreende-se, portanto, que a violência insurgente e revoltosa de que falam Fanon e Sartre seja uma espécie de violência ativa e reativa, desesperada, pois empreendida por aqueles que já se consideravam mortos, subjugados. Forjados na violência da exploração e expropriação, os explorados recorrem à violência como meio possível de se insurgir, de sublevar-se contra as forças históricas que lhes oprimem, imobilizam e matam. Sem necessariamente entrarmos na querela entre os defensores da violência como recurso político e os advogados da não-violência como única solução eticamente viável, o importante aqui é retermos que, de maneira generalista, a explosão violenta dos levantes é, em geral, precedida de outras violências, contra as quais as pessoas se erguem, revoltam-se. As mortes de George Floyd, do menino João Pedro e de Beto foram sucedidas, muitas vezes, por manifestações acaloradas, violentas, rapidamente enquadradas pela imprensa e pelos governos como vandalismos, depredações, termos estratégicos para legitimar a violência repressiva e deslegitimar a reativa.

Intuitivamente, somos levados a crer que a função das imagens seria, de saída, registrar e testemunhar essas múltiplas aparições da violência: opressiva, reativa, repressiva. Se, como diria Nancy (2000), a própria violência manifesta-se imprimindo sua marca, produzindo-se como imagem, poderíamos rapidamente concluir que à imagem cabe capturar essas marcas - e até mesmo denunciá-las. Entretanto, diríamos que as 
imagens estão aquém e além dessa tarefa. Por um lado, jamais uma imagem dará conta de fazer a síntese de uma experiência violenta. Por outro, as imagens tocam uma dimensão muito concreta da violência: sua monstruosidade, sua profundidade sem fundo. Essa seria, para Nancy (2000), a diferença entre imagens da arte e imagens simplesmente violentas:

A violência da arte difere daquela dos cortes, não porque a arte permaneça na aparência, mas, ao contrário, porque ela toca o real - que é sem fundo - enquanto que o corte existe por si-mesmo e no instante de seu próprio fundo. É já uma arte - como se diz em Francês -, cabe à arte em geral, muito além ou muito aquém da estética, saber distinguir entre uma imagem sem fundo e uma imagem que é apenas e tão somente um corte (NANCY, 2000, p. 8, tradução nossa, grifos do autor).

Essa argumentação sobre a relação ambígua da imagem com a violência só nos parece plenamente elucidada quando tomamos como exemplo uma imagem que, justamente, oscila entre esses campos aparentemente separados, da arte e das imagenscorte, das imagens violentas. Trata-se da fotografia de Nay Jinknss, resultante de um ensaio produzido para o terceiro episódio do programa televisivo Arte na fotografia, exibido pelo canal Arte 1 em 12 de junho de 2020, cujo tema era "Atemporalidade". Na imagem, feita meses antes daqueles crimes de grande comoção e das manifestações antirracistas subsequentes, vê-se o corpo de um homem negro deitado no chão, com o rosto sob as botas de outra pessoa. A fotografia é feita em preto e branco, com baixa luminosidade, contornos imprecisos e pouca nitidez. A oscilação de foco e o jogo de luzes e sombras remete a uma atmosfera onírica, à maneira das rememorações e flashbacks cinematográficos. Em primeiro plano, o asfalto granulado sobre o qual o homem é pisoteado. No centro, o rosto sob o calçado, que, junto com a calça, lembra um uniforme militar. Ao fundo, apenas a silhueta de cavaletes de sinalização abertos na rua e um poste no estilo colonial. Pela composição visual e pela natureza do ensaio, feito sob o roteiro de um programa televisivo no qual fotógrafos competem entre si por meio da produção de imagens, tudo leva a crer que aquela é uma fotografia encenada especialmente para aquela ocasião - embora essa cena, historicamente, não seja ficcional. 
Figura 1 - "Atemporalidade", de Nay Jinknss

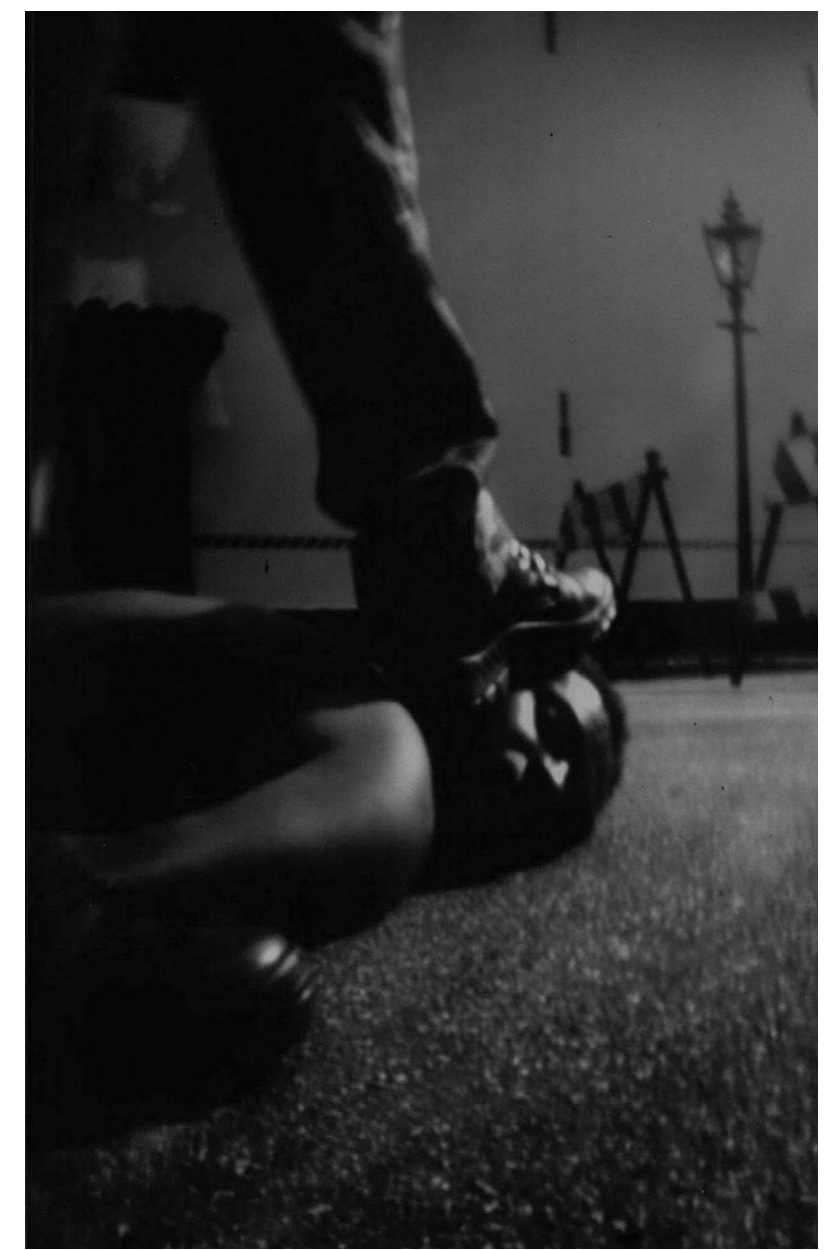

Fonte: https://nitidafotografia.wordpress.com/2020/06/16/nitidaentrevista-nay-jinknss/. Acesso em: 15 fev. 2021.

Sobre essa fotografia, Nay Jinknss escreveu em uma de suas redes sociais:

Foi impossível ouvir esse tema e não lembrar de como a sociedade nos enxerga, nos silencia e nos mata. Essas imagens foram feitas no Pátio do Colégio em São Paulo. Mas poderia ter sido na Terra Firme, no Complexo do Salgueiro, em Mineápolis. Poderia ter acontecido com o Diogo, como com tantos de nós. A gente precisa reparar urgentemente essas narrativas que nos colonizam e nos apagam (JINKNSS, 2020).

Embora possamos dizer que a fotografia de Nay Jinknss não documenta, propriamente, os acontecimentos de 2020, o pano de fundo dessa imagem é, justamente, o da historicidade da violência racista em torno da qual esses mesmos eventos orbitaram. Daí insinuam-se, ao mesmo tempo, a atualidade e a "preteridade" da imagem e do golpe 


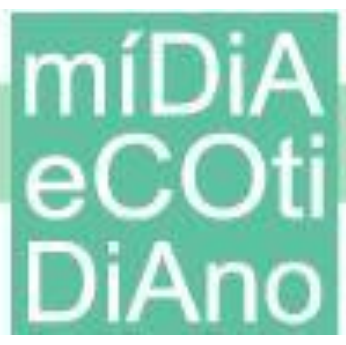

que ela institui. A fotógrafa paraense escolheu a violência racista como índice de uma "atemporalidade", tema encomendado para sua imagem. Simultaneamente, ela fez do registro a figuração de um vulto, tocando, justamente, na dimensão monstruosa a que chega o racismo estrutural - para muitos pouco nítida, para outros até negada. Mais do que representar um golpe, um corte, um gesto violento em si, Nay Jinknss optou por "tocar o real" sem a pretensão de alcançar seu fundo: foi além da superficialidade da marca da violência, repetida com frequência nos noticiários para alimentar um regime de visibilidade racista. Aquela é a imagem de um gesto sem sujeitos, sem tempo, nem espaço, mas que, no entanto, repete-se incessantemente. A expressão visual de um devir violento da experiência do homem negro: um devir cuja abertura e contingência - o devir minoritário, como definem Deleuze e Guattari - vêm sendo historicamente limitadas, cerceadas. Ao demonstrar a agressão à qual as pessoas e os corpos negros estão diariamente submetidos, aquela fotografia captura um aspecto específico do levante, nem sempre presente nas imagens governadas pela factualidade dos eventos: a experiência da violência motivadora das insurgências, as violações que precedem os rompantes de raiva e revolta daqueles que são subjugados sob os coturnos.

\section{Quando tudo se inflama}

Assumir que a violência seja subjacente às sublevações e, ainda assim, considerá-las ações políticas legítimas dentro dos ideais democráticos pressupõe certo exercício crítico. Isso porque, por via de regra, a violência é considerada uma espécie de “outro" da política (BALIBAR, 2015). Nesse sentido, explica É. Balibar, "no processo real da política e de sua história, a violência faz parte das condições, dos meios e, consequentemente, faz parte dos fins, porque estes são imanentes aos meios ou acabam sendo. Trata-se de examinar as formas, as modalidades, as transformações da violência" (2015, p. 48, tradução nossa). Há, por certo, uma longa série de ressalvas a serem feitas, sobretudo quanto à distinção entre violência e extrema violência, entre agressão destinada a objetar a resistência e a reação desesperada em autodefesa, entre carrascos e vítimas, entre violência aniquiladora e violência restauradora da cidadania. Entretanto, e voltando aos preceitos benjaminianos, considerar a violência como parte das relações políticas significa admitir sua capacidade de não apenas instituir, estabelecer relações jurídicas, 
mas também de modificá-las. Não por acaso, a maioria das grandes conquistas e dos grandes retrocessos relacionados, por exemplo, aos direitos dos cidadãos, é atravessada por lutas políticas que envolveram processos violentos: das manifestações acaloradas às violências institucionais.

A longa história dos levantes é carregada de episódios violentos e sanguinários, de mártires e vilões, de crimes e sacrifícios. Segundo G. Didi-Huberman, há um determinado momento desses conflitos em que tudo se inflama, em que os desejos e ações ardem em brasas:

Então tudo se inflama. Tem quem veja nisso apenas o puro caos. No entanto, outros veem surgir formas de um desejo de ser livre, formas de vida em comum durante as greves. Dizer "manifestamos" é constatar mesmo com espanto, mesmo sem compreender - que algo surgiu, algo decisivo. Mas foi preciso um conflito. É um tema importante para a moderna pintura da história (de Manet a Polke) e para as artes visuais em geral (fotografia, cinema, vídeo, arte digital). Os levantes às vezes produzem apenas a imagem de imagens quebradas: vandalismos, um tipo de carnaval negativo. Mas a arquitetura provisória dos levantes se constrói sobre essas ruínas: coisas paradoxais, moventes, feitas disso e daquilo, como as barricadas. Depois as autoridades reprimem a manifestação, quando já não resta aos manifestantes nada além da força do desejo (a força, não o poder). Por isso, na história, tantas pessoas morreram por terem se levantado (DIDI-HUBERMAN, 2017a, p. 207).

Esse momento de ruptura, de produção de ruínas não é, para o filósofo, o signo de uma destruição. Trata-se de uma reapropriação dos espaços, dos tempos, dos objetos, de si. O repertório dessas ações políticas é significativo, como mostram Ogien e Laugier (2011): a abstenção, o boicote, a petição, a manifestação, a greve, o uso moderado ou simbólico da violência, o tumulto, a desobediência civil enquanto disposição para a recusa a uma lei ou a uma de suas disposições, ainda que ela tenha sido instituída por uma maioria de representantes do povo. A essa lista podemos acrescentar ainda bloqueios, quebra-quebras, saques, sabotagem, motins, ocupações, greves de fome e outras formas de autoflagelo, além de ações em caráter mais simbólico e, digamos, diplomático, como abraços coletivos, encenações, mutirões. O repertório de ações repressivas também é longo: cercos, bloqueios, bombas de dispersão, sprays de pimenta, golpes de cassetetes e 
escudo antimotim, uso de armas de fogo com munição comum ou de impacto cinético (balas de borracha, como são conhecidas), jatos d'água, uso de cavalaria e de cães...

Em sua defesa da violência política, Fanon (1968) argumenta que as reações violentas às opressões colonialistas são formas de introduzir uma agitação no mundo, de sacudir estruturas históricas de subjugação. Para ele, o uso simétrico da violência, isto é, a apropriação da violência por quem historicamente é dela vítima é condição da afirmação da própria simetria das vidas que importam, da cidadania e mesmo da humanidade em disputa. Se aplicarmos esse esquema argumentativo ao calor dos levantes, ao momento em que os conflitos estão abrasados, parece-nos igualmente previsível que o recurso à violência venha à tona por todas as partes, sobretudo quando compara-se a disparidade de instrumentos de defesa e ataque dos manifestantes e das forças policiais do Estado e a própria disparidade na quantidade de vítimas feridas ${ }^{4}$.

Um dia após o assassinato de Beto no estacionamento de um supermercado de Porto Alegre (RS) foi realizada a $17^{\mathrm{a}}$ Marcha da Consciência Negra, em São Paulo. A certa altura do protesto, um grupo de manifestantes invadiu um supermercado da mesma rede, jogou objetos contra a fachada da loja e ateou fogo em prateleiras e gôndolas. Nas imagens de Amanda Perobelli para a agência britânica de notícias Reuters, dois gestos opostos: na primeira, um homem atira um cone de sinalização na fachada do shopping em que fica o supermercado alvo dos protestos; na segunda, uma mulher uniformizada, provavelmente funcionária do supermercado, aciona um extintor de incêndio para apagar as chamas em um cesto de produtos, no interior da loja.

\footnotetext{
${ }^{4}$ Esse foi o caso do fotógrafo Sérgio Silva, alvejado no olho por uma bala de borracha enquanto registrava um protesto no centro de São Paulo em junho de 2013, período de grandes agitações de rua no país. Sérgio perdeu a visão na mesma hora, conforme relata em Memória ocular (2018), livro com o depoimento dele e de outras vítimas da violência policial empreendida naquelas manifestações.
} 


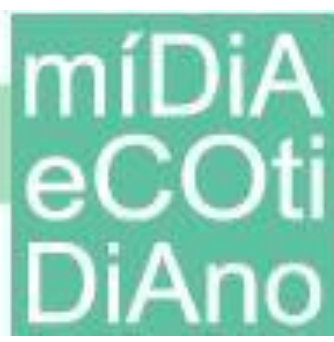

\section{PPGMC}

uff

Figuras 2 e 3 - Fotografias de Amanda Perobelli/Agência Reuters
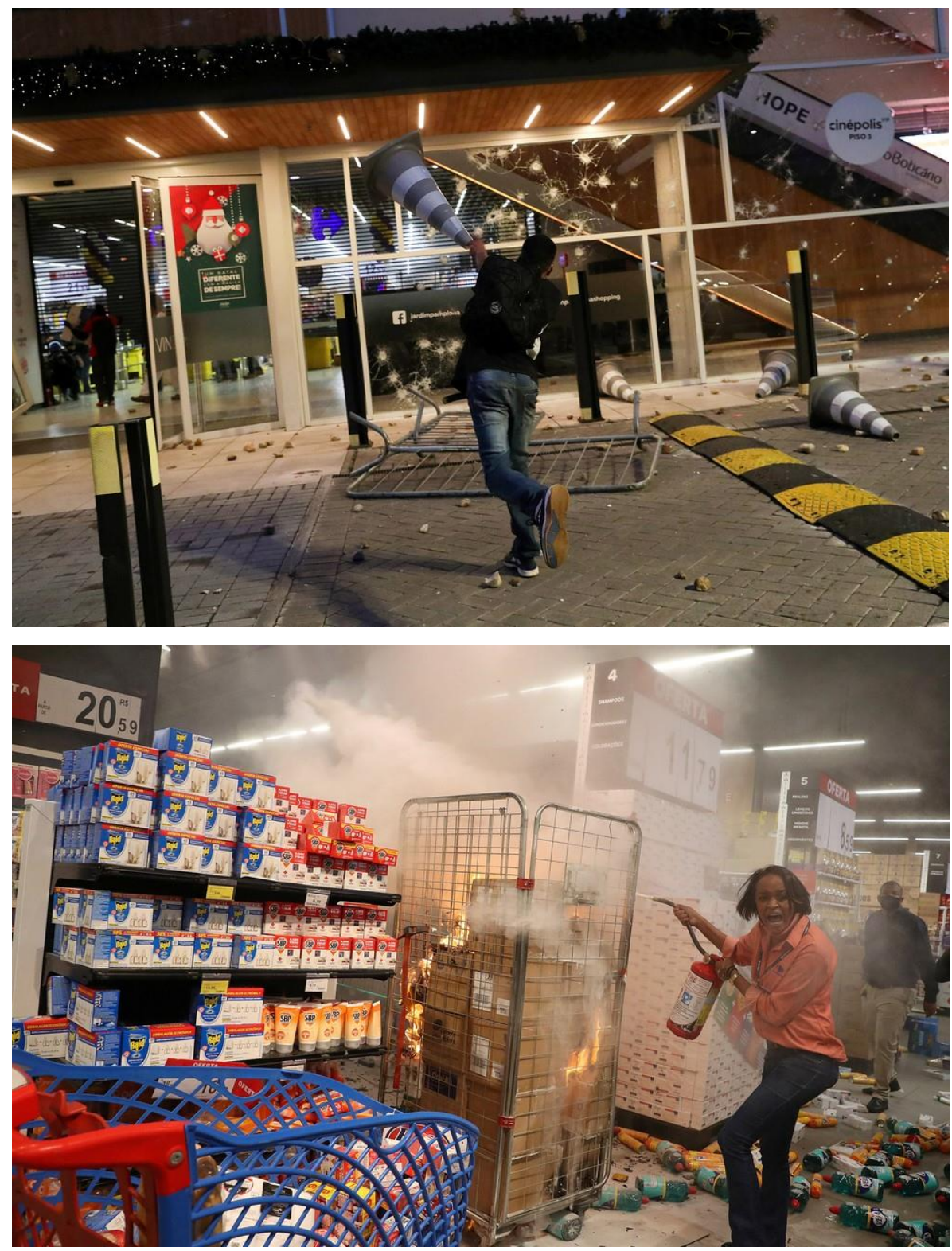

Fonte: https://g1.globo.com/sp/sao-paulo/noticia/2020/11/20/manifestantes-fazemato-em-sp-pedindo-justica-para-joao-alberto-durante-17a-marcha-da-consciencianegra.ghtml. Acesso em: 15 fev. 2021.

Ambas as imagens capturam o calor dos conflitos, a ação destruidora dos manifestantes. As fotografias, destinadas a um regime midiático de visibilidade, documentam a violência e suas marcas como expressão da raiva e da indignação daqueles que se sublevam. Contra a destruição de uma vida, a demolição de estruturas materiais. A ironia desse gesto é a de que os manifestantes de São Paulo realizaram, precisamente, 


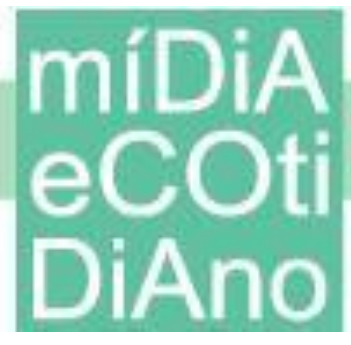

aquilo de que Beto fora acusado: a perturbação do funcionamento da loja, a ameaça aos bens materiais e mercadorias à venda. Mas as imagens parecem não dar conta de todas essas nuances. Na primeira, um manifestante solitário projeta-se contra um prédio comercial, atirando um objeto de plástico. Na segunda, uma mulher negra desespera-se para controlar o fogo ateado pelos manifestantes. Pela composição visual, são fotografias tiradas da urgência dos eventos: a linha do horizonte levemente inclinada, a dinâmica actancial dos indivíduos, a quantidade e dispersão dos elementos. Nenhuma dessas formas expressivas parece explorar, no entanto, aquela profundidade sem fundo das imagens da violência. São imagens-corte, imagens-golpe, que se prestam de bom grado a um regime informacional e registram pequenas centelhas de momentos coletivos de indignação. Não se quer, com isso, exigir mais do que as imagens possam oferecer. A questão não é cobrar das imagens, mas refletir sobre os enquadramentos da violência dos levantes. Impõe-se, nesse sentido, uma ressignificação dessa destruição: fazer dos escombros a matéria-prima da reconstrução, das ruínas o simbolismo de estruturas que precisam tombar, dos gestos violentos a ação política que resta.

\section{O levante impedido}

Em 7 de junho de 2020, duas semanas após a morte de George Floyd e em meio à onda crescente de protestos no mundo, uma manifestação com a bandeira antirracista foi marcada pela internet para o início da manhã, no Mercado de São Brás, em Belém (PA). Ao chegarem ao local, os manifestantes depararam-se com policiais militares preparados para dispersar o protesto, impedindo que ele se realizasse. Os policiais faziam cumprir um decreto governamental então em vigor que proibia aglomerações de mais de dez pessoas como forma de conter o avanço da pandemia do Novo Coronavírus. Os oficiais não apenas contiveram o movimento - formado, em sua maioria, por jovens negros vestidos com roupas pretas e de máscara na parte inferior do rosto - como revistaram as pessoas e detiveram algumas "para averiguação" na delegacia. À imprensa, a polícia informou que foram encontradas armas brancas e coquetéis molotov entre os pertences de manifestantes. Nenhuma imagem desses objetos foi divulgada. Após negociação com a Polícia Militar, os participantes do protesto tiveram a permissão para que um grupo de dez pessoas realizasse o ato simbolicamente e o registrasse. 
A violência com que o Estado agiu para reprimir a manifestação fica evidente na série de imagens feitas daquele levante impedido. Na fotografia de Thiago Gomes, publicada pelo jornal O Liberal, vê-se uma mulher jovem, de máscara e óculos, sentada no chão de pernas cruzadas e braços para trás, sugerindo que ela esteja algemada. O rosto dela está virado para cima, esboçando algum tipo de reação ou expressão não identificável. À direita, um policial fardado e equipado com uma arma pesada espreita o fotógrafo por entre a fresta a partir da qual a imagem foi capturada, ao mesmo tempo em que parece vigiar a mulher e as demais pessoas detidas, que não aparecem na cena. A fotografia foi tirada já na delegacia para onde os manifestantes foram levados. $\mathrm{O}$ corpo subjugado da jovem diante da postura rigorosa do policial fortemente armado evidencia o contraste entre a suposta ameaça violenta do levante e a repressão legitimada em defesa da ordem jurídica. A própria natureza furtiva daquela imagem já demonstra essa atmosfera de censura, interdição e controle da vontade popular a partir de ações pouco transparentes do Estado. Embora houvesse amparo legal para a interdição de aglomerações em meio à maior crise de saúde pública do último século, a violência intimidadora premeditada e o recolhimento de manifestantes sem o devido flagrante também sugerem violações do estado de direito. 
Figura 4 - Fotografia de Thiago Gomes/O Liberal

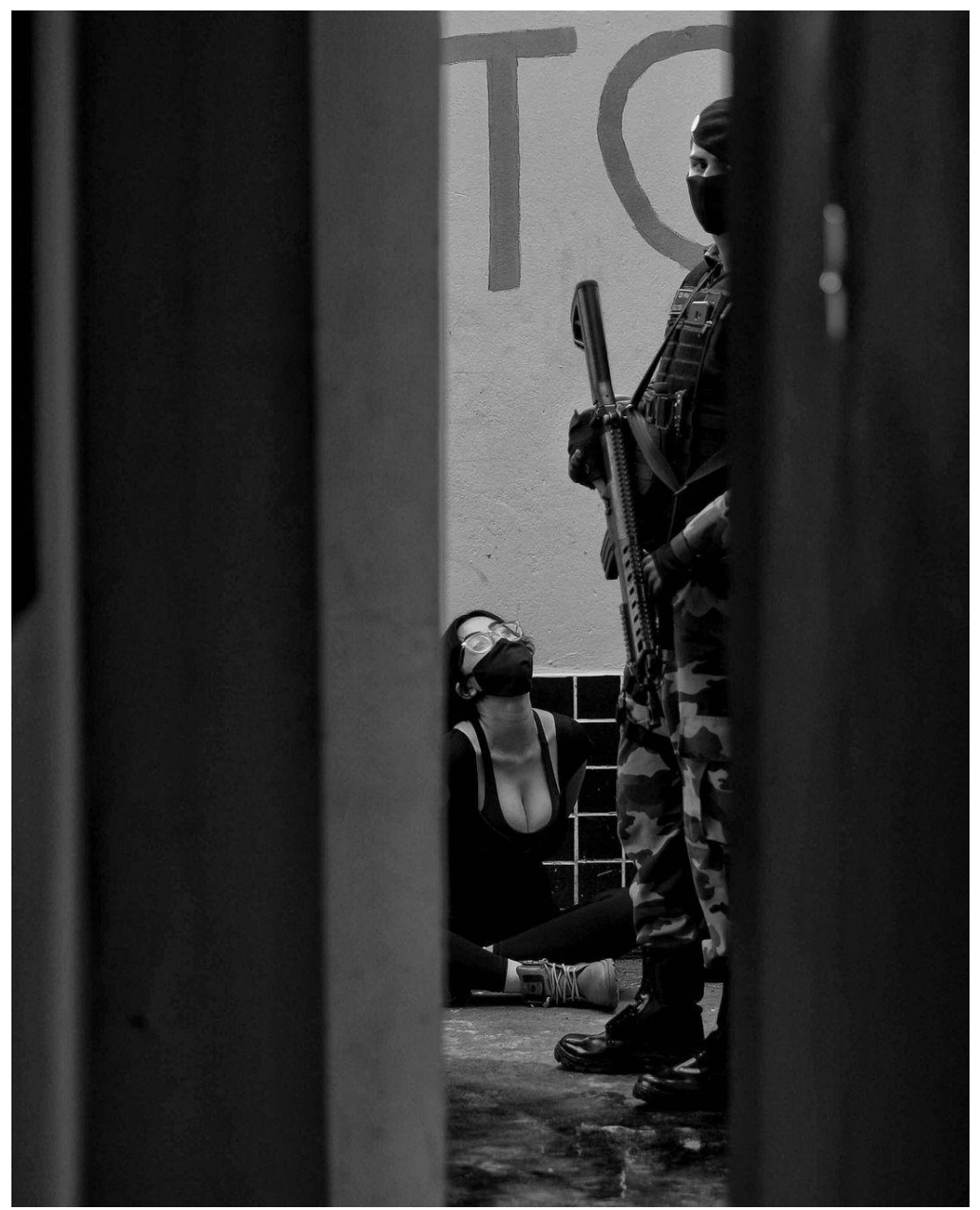

Fonte: https://www.instagram.com/thiago_gomes_photography/. Acesso em: 15 fev. 2021.

A fotografia de Thiago Gomes captura não apenas uma forma de violência institucional precipitada sobre o direito que os cidadãos têm de se manifestar e expressar sua indignação, mas também certo cinismo de uma "política de imobilidade" cara a certas lideranças políticas - para usarmos os termos de Frantz Fanon. Por política de imobilidade o autor compreende os dispositivos de controle sobre os indivíduos subjugados, que vão desde o pacifismo complacente da intelectualidade até os mecanismos jurídicos que coíbem os movimentos que ameaçam desarranjar as estruturas de poder. Ao enquadramento recorrente dos manifestantes como baderneiros, agitadores, aquela imagem opõe um outro prisma sobre essa organização de forças: uma jovem é detida de forma aparentemente arbitrária e mantida por força policial excessiva quando 


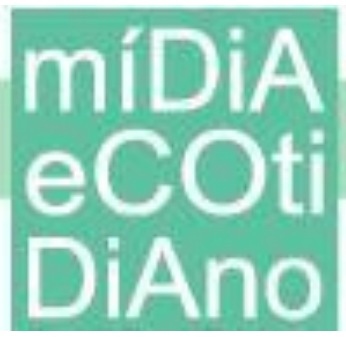

comparada à ameaça que ela própria poderia oferecer. A imagem acaba por revelar com precisão esses dois aspectos elementares e recorrentes dos levantes: primeiro, a assimetria de forças e poderes entre os que se sublevam e os que subjugam; segundo, a violência e a intimidação como recursos utilizados para conter a potência das insurgências.

A respeito desses pontos críticos, é importante evocarmos pelo menos duas constatações sobre a relação entre violência, imagens e levantes. A primeira, já mencionada anteriormente, diz respeito à crítica da violência como instrumento de instituição e manutenção do direito, da ordem, das estruturas e das instituições. Como argumentou W. Benjamin (1986), a toda violência desse tipo - inclinada à imobilidade, ao engessamento é inerente um caráter legislador. Daí porque ela é mobilizada de modo tão eficaz contra a violência ameaçadora da ordem: o risco virtual de uma manifestação com dimensões e consequências não previstas constitui-se como índice suficiente para legitimar uma intervenção. Mas aí entra a imagem em seu trabalho de "tocar o real" e revelar as marcas deixadas pela violência institucional. Talvez por um momento de distração das autoridades, o fotógrafo invadiu um espaço de poder e furtou um momento, uma temporalidade na qual o exercício desse poder se realizava exageradamente e longe dos nossos olhos.

Em segundo lugar, a interdição jurídica e policial da manifestação remete a um segundo dilema dos levantes: a vulnerabilidade dos corpos. Apesar das razões compreensíveis para que as autoridades públicas coíbam aglomerações, a concorrência entre o direito de reunião e o dever de zelar pela saúde coletiva não deixa de trazer à tona o fato de que, em certas manifestações políticas, o que está em jogo é o próprio direito de poder lutar. "Algumas vezes o objetivo de uma luta política é exatamente superar as condições indesejadas da condição corporal. Outras vezes a exposição deliberada do corpo a uma possível violência faz parte do próprio significado de resistência política" (BUTLER, 2018, p. 140). A rua, o espaço público também são, afinal, um direito pelo qual as pessoas lutam: são uma plataforma de atuação política ou, para usarmos uma expressão da autora, são uma "infraestrutura da ação política".

Se, por um lado, a pandemia gerou certa elasticidade na aplicação de normas jurídicas elementares como os direitos de ir e vir e de reunião, por outro lado a questão da violência institucional trazida à tona pelo levante pós-George Floyd em Belém é mais pragmática do que propriamente jurídica. A imposição assimétrica da força policial, via 
intimidação e coação, tal como revelada na fotografia, desenha nitidamente os excessos na aplicação da norma - embora possa-se discutir a própria norma como excesso. Nesse sentido, e diferentemente das imagens de Amanda Perobelli, aqui a imagem não se curva à contemplação da violência. Além de revelar as impressões dos abusos e violações, ela própria resiste ao cerco e captura as múltiplas investidas contra os corpos e sujeitos revoltosos.

\section{Considerações finais: sobre a força percussiva das imagens}

A partir da fotografia de Nay Jinknss, vimos como uma imagem é capaz de evocar certa historicidade (ou "atemporalidade") da experiência da violência catalisadora das insurgências. Nos registros fotojornalísticos de Amanda Perobelli, percebemos como a imagem pertencente ao regime informacional se coloca no centro dos eventos e captura os momentos mais acalorados dos conflitos, sem necessariamente ir além de seu próprio recorte visual e das marcas mais evidentes da violência dos levantes. Por outro lado, esse mesmo regime de visibilidade da informação jornalística também pode, como mostra a fotografia de Thiago Gomes, recusar-se a apenas explorar as marcas da violência e esquivar-se das interdições ao olhar. Mas ainda nos resta refletir mais diretamente sobre a força percussiva das próprias imagens. E os protestos após a morte de George Floyd foram pródigos em produzir imagens marcantes, como a do prédio completamente em chamas em Minneapolis retratado na fotografia de Mark Vancleave distribuída pela agência Associated Press. 
Figura 5 - Fotografia de Mark Vancleave/Associated Press

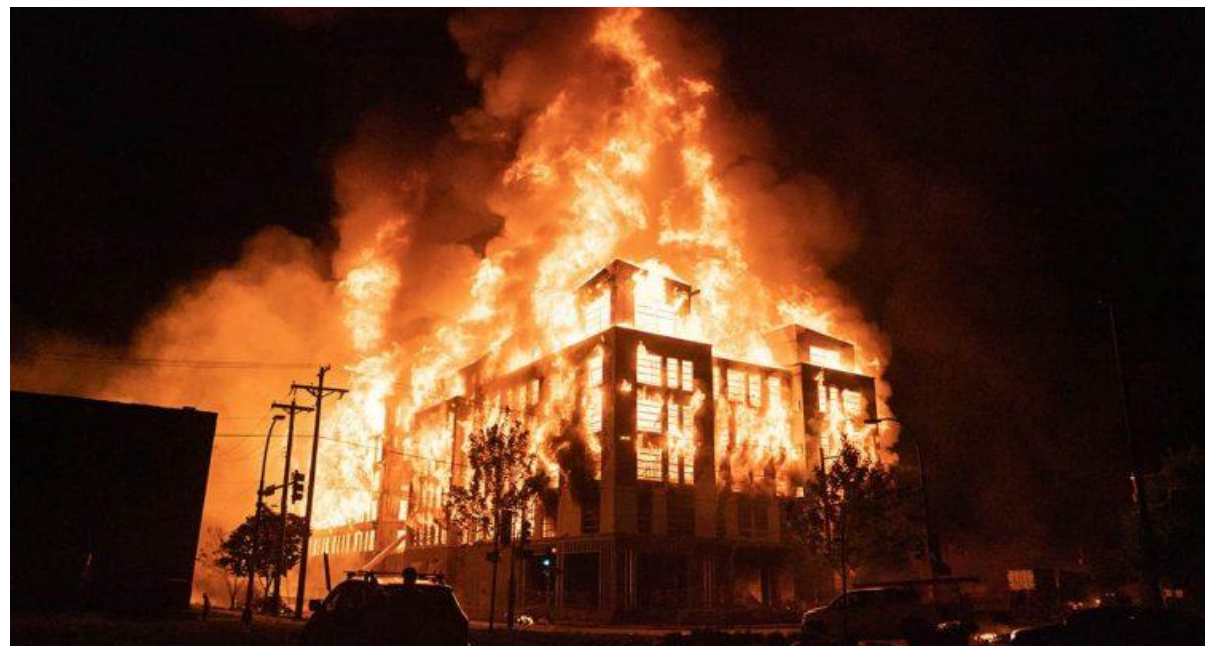

Fonte:https://www.arkansasonline.com/news/2020/jun/15/officers-resigning-inminneapolis/. Acesso em: 15 fev. 2021.

Dois dias após a morte de George Floyd, a cidade estadunidense de Minneapolis ainda estava sitiada pelos protestos. Os sistemas de transporte foram suspensos, o comércio fechado e as ruas tomadas por manifestantes. Prédios e automóveis foram queimados. Quanto mais a polícia agia na tentativa de controlar os distúrbios, mais os manifestantes reagiam contra as forças de segurança. Esse conflito abrasado gerou uma das imagens mais proeminentes dos levantes antirracistas após a morte de Floyd. Um prédio ainda em obras de quase 200 apartamentos foi totalmente destruído pelas chamas. A imagem, recortada e reeditada inúmeras vezes, circulou o mundo e com as mais diversas referências. No Brasil, as primeiras informações davam conta de que aquele prédio seria de uma delegacia. As chamas em meio à estrutura e as longas colunas de fumaça produziram uma espécie de recorte cinematográfico do levante. A fotografia reunia todos os indícios de que a fúria revoltosa tomava conta da cidade e estava fora de controle, além de todos os elementos visuais de uma imagem paradigmática: a luz incandescente emanando das labaredas formava um halo brilhante em torno do prédio, envolto pela sombra noturna. Não seria exagero compará-la à composição visual de um cartaz de filme de ação no qual, em geral, as explosões são tão protagonistas quanto os personagens.

Fotografias como a do prédio em chamas servem para "espraiar" a atmosfera de insatisfação e revolta, para usarmos outro termo caro a Frantz Fanon. Mas também acabam se prestando aos mecanismos de controle e enquadramento que fazem dos 


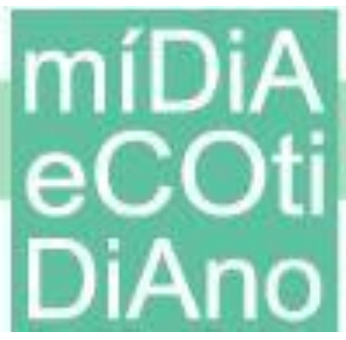

levantes fenômenos tão incompreendidos por aquelas pessoas que deles não tomam parte. “A imagem”, diz Rancière (2012, p. 92), “não é o duplo de uma coisa. É um jogo complexo de relações entre o visível e o invisível, o visível e a palavra, o dito e o não dito". O que chamamos de imagem, e aí se incluem especialmente as imagens dos regimes jornalísticos de visibilidade, é o elemento de um dispositivo que cria certo senso de realidade, pois organiza formas de ver, mostrar, sentir, compreender. Por isso, e contraditoriamente, parece-nos que a mesma grandiloquência da imagem do prédio em chamas em Minneapolis que faz dela paradigmática acaba por obliterar as motivações, os agentes e os afetos daquele levante em favor das marcadas deixadas pela violência destruidora. Novamente, estamos diante de escombros sem projetos ou perspectivas de reconstrução, embora os gritos, as bandeiras e os cartazes tenham reivindicado, repetidamente, a importância das vidas negras e da necessidade de desconstrução da desigualdade a todo custo.

Resta-nos comentar um último aspecto da relação entre imagens, levantes e violências. É necessário confrontar permanentemente o lugar das imagens perante o dilema da violência, dando ênfase, sobretudo, ao imperativo de descontinuação da espiral de violações. Mesmo partindo daquela suspensão moral na crítica da violência, ao admitir que ela subjaz aos levantes e não é necessariamente o oposto da política, ainda será necessário fazer o movimento contrário e refletir sobre o papel das imagens na reformulação dos regimes de visibilidade que criminalizam as lutas políticas e seus sujeitos, que estigmatizam corpos e falas, que condicionam nossas disposições afetivas diante do intolerável de certos arranjos de poder e daqueles que buscam reordená-los. Conforme argumenta Schwarte (2018), a forma da imagem condiciona a forma dos levantes, que podem ou não se abrir para que os sujeitos ocupem seu espaço de aparição e façam sua política.

\section{Referências}

BADIOU, Alain. The rebirth of history: Times of riots and uprisings. London, New York: Verso Books, 2012.

BALIBAR, Étienne. Violencia, política, civilidad. Ciencia Política, v. 10, n. 19, p. 4567, 2015. 
BENJAMIN, Walter. Crítica da violência: crítica do poder. In: BENJAMIN, Walter. Documentos de cultura, documentos de barbárie: escritos escolhidos. São Paulo: Cultrix; Editora da Universidade de São Paulo, p. 160-175, 1986.

BLACK LIVES MATTER GLOBAL NETWORK FOUNDATION. Black Lives Matter, [2020]. Herstory. Disponível em: https://blacklivesmatter.com/herstory/. Acesso em: 14 fev. 2021.

BUTLER, J. Levante. In: DIDI-HUBERMAN, G. Levantes. São Paulo: Sesc, 2017, p. 23-36.

BUTLER, Judith. Corpos em aliança e a política das ruas: notas para uma teoria performativa de assembleia. Rio de Janeiro: Civilização Brasileira, 2018.

DIDI-HUBERMAN, G. Levantes. São Paulo: Sesc-SP, 2017a.

Através dos desejos (fragmentos sobre o que nos subleva). In: DIDI-

HUBERMAN, G. Levantes. São Paulo: Sesc-SP, 2017b, p. 289-383.

Désirer désobéir: Ce qui nous soulève, 1. Paris: Minuit, 2019.

FANON, Frantz. Os condenados da terra. Rio de Janeiro: Civilização Brasileira, 1968.

JINKNSS, Nay. $3^{\circ}$ ep - Atemporalidade. São Paulo, 12 jun. 2020. Instagram:

@ nayjinknss. Disponível em: https://www.instagram.com/p/CBWuixUBx-O/. Acesso em: 20 fev. 2021.

LAUGIER, Sandra; OGIEN, Albert. Pourquoi désobéir en démocratie? Paris: La Découverte, 2011.

NANCY, Jean-Luc. Image et violence. Le Portique. Revue de philosophie et de sciences humaines, n. 6, p. 1-11, 2000.

RANCIÈRE, Jacques. O espectador emancipado. São Paulo: WMF Martins Fontes, 2012.

RANCIÈRE, Jacques. Um levante pode esconder outro. In: DIDI-HUBERMAN, G. Levantes. São Paulo: Sesc-SP, 2017, p. 63-70.

SARTRE, Jean-Paul. Prefácio. In: FANON, Frantz. Os condenados da terra. Rio de Janeiro: Civilização Brasileira, 1968.

SCHWARTE, Ludger. THE PEOPLE-IMAGE: the political philosophy of georges didihuberman. Angelaki, v. 23, n. 4, p. 80-90, 2018.

SILVA, Sérgio; BREDA, Tadeu. Memória ocular: cenas de um estado que cega. São Paulo: Elefante, 2018. 